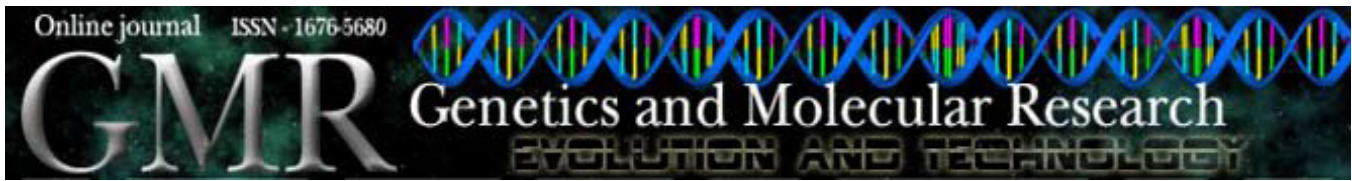

Short Communication

\title{
Isolation and characterization of microsatellite markers in the armored catfish Hypostomus gymnorhynchus (Loricariidae)
}

M.P.C. Telles ${ }^{1}$, L.V. Resende ${ }^{1}$, R.P.V. Brondani ${ }^{2}$, R.G. Collevatti ${ }^{1}$, M.C. Costa ${ }^{3}$ and N.J. Silva Júnior ${ }^{3}$

${ }^{1}$ Laboratório de Genética e Biodiversidade, Instituto de Ciências Biológicas, Universidade Federal de Goiás, Goiânia, GO, Brasil ${ }^{2}$ Laboratório de Biotecnologia, Empresa Brasileira de Pesquisa Agropecuária Arroz e Feijão, Santo Antônio de Goiás, GO, Brasil

${ }^{3}$ Systema Naturae Consultoria Ambiental Ltda., Goiânia, GO, Brasil

Corresponding authors: M.P.C. Telles

E-mail: tellesmpc@gmail.com

Genet. Mol. Res. 9 (3): 1770-1774 (2010)

Received May 5, 2010

Accepted July 11, 2010

Published September 8, 2010

DOI 10.4238/vol9-3gmr868

\begin{abstract}
We isolated and characterized 10 microsatellite loci in the armored catfish (Hypostomus gymnorhynchus, Loricariidae), using a genomic shotgun library to obtain the repetitive sequences. Twenty-four primers were designed and 14 individuals of $H$. gymnorhynchus from the Caiapó River, in central Brazil, were genotyped using these primers to analyze the polymorphism at each locus. All loci showed low polymorphism, with a low number of alleles per locus (1 or 2), except locus Hg_E19, which had 11 alleles. Expected heterozygosities for polymorphic loci ranged from 0.182 to 0.901 . Combined paternity exclusion probability (0.857) was low and combined genetic identity (0.0026) was high, when we examined parentage. The low degree of polymorphism that we detected may be due to the small sample size and the small microsatellite size, despite the large motif size.
\end{abstract}

Key words: Cerrado; Loricariidae; Microsatellite; Shotgun library 
Hypostomus gymnorhynchus (Loricariidae) belongs to one of the largest and most taxonomically complex Pisces families, with more than 670 species. The family is Neotropical, distributed from Costa Rica to Argentina (Covain and Fisch-Muller, 2007). The genus Hypostomus is widespread in the Neotropics, but many species are endemic to small streams, and no information about geographical distribution, ecology or genetics is available for H. gymnorhynchus. In the last decades, the number of hydroelectric power plants has increased in Brazil. This may cause habitat loss and fragmentation and the isolation of fish populations, especially migratory species. Thus, the availability of molecular tools for population genetic studies is highly important to evaluate the impact of this process in the long-term genetic viability of these populations.

Due to the high genetic information content, microsatellites are one of the most useful molecular markers to estimate population genetic parameters, and also for their codominant allelic patterns, critical for the investigation of gene flow patterns and parentage composition (Morgante and Olivieri, 1993). Despite the advantages of microsatellite makers in terms of investigating the population genetics of various species, reports on the development, characterization and use of microsatellite loci in Neotropical fish species are still scarce (Revaldaves et al., 2005; Carvalho-Costa et al., 2006; Morelli et al., 2007; Batista et al., 2009). In this study, we report the discovery and genetic characterization of 10 microsatellite loci for $H$. gymnorhynchus.

Instead of creating a genomic library enriched for microsatellites, genomic shotgun sequencing coupled with bioinformatics tools was explored to obtain the microsatellite markers. First, genomic DNA was extracted from muscle strips using the Genomic Prep ${ }^{\mathrm{TM}}$ Cells and Tissue DNA Isolation Kit (GE HealthCare, Sweden). Total genomic DNA $(2.0 \mu \mathrm{g})$ from one individual of $H$. gymnorhynchus was sheared using a sonicator, to obtain fragments from $200 \mathrm{bp}$ to $1.0 \mathrm{~kb}$. Fragments were recovered and cloned into pMOSBlue dephosphorylated blunt vector using the Blunt-ended PCR Cloning $\mathrm{Kit}^{\circledR}$ (GE HealthCare). Cloned fragments were transformed into chemically competent pMOSBlue ${ }^{\circledR}$ cells (GE HealthCare) and plated onto Luria-Bertani (LB) plates containing ampicillin and X-Gal. Recombinant clones were grown overnight in liquid ampicillin LB medium, and plasmid DNA was extracted using a standard protocol (Sambrook and Russell, 2001). DNA inserts were sequenced using U19 primer in a 3100 automated DNA sequencer (Applied Biosystems, USA) using the DYEnamicET terminator kit (GE Healthcare), according to manufacturer instructions. The reads were filtered by their quality and length (phred value $\geq 20$; length $\geq 150$ ) and analyzed for their nucleotide content. The reads obtained were screened for microsatellites (di-, tri-, and tetranucleotides) using the TROLL software (Martins et al., 2006). Primers were designed using the web service primer designer at http://wsmartins.net/primerdesign/.

Polymorphisms at the loci were assessed for 14 individuals of $H$. gymnorhynchus, sampled in the Caiapó River, in Northwest Goias State, in Central Brazil. Amplification was performed in a total reaction volume of $15 \mu \mathrm{L}$ containing $25 \mathrm{ng}$ template DNA, $1.8 \mu \mathrm{M}$ of each primer, $1 \mathrm{U}$ Taq DNA polymerase (Phoneutria, Brazil), $325 \mu \mathrm{M}$ of each dNTP, 0.13 $\mu \mathrm{g}$ BSA and $1 \mathrm{X}$ reaction buffer $(10 \mathrm{mM}$ Tris- $\mathrm{HCl}, \mathrm{pH} 8.3,50 \mathrm{mM} \mathrm{KCl}, 1.5 \mathrm{mM} \mathrm{MgCl}$ ). Polymerase chain reactions (PCRs) were carried out in thermal cycler with the following conditions: $94^{\circ} \mathrm{C}$ for $5 \mathrm{~min}$ (one cycle), $94^{\circ} \mathrm{C}$ for $1 \mathrm{~min}, 54^{\circ}$ to $68^{\circ} \mathrm{C}$ (according to the primer annealing temperature; see Table 1$)$ for $1 \mathrm{~min}, 72^{\circ} \mathrm{C}$ for $1 \mathrm{~min}(30$ cycles $)$, and $72^{\circ} \mathrm{C}$ for $7 \mathrm{~min}$ (one cycle). Individuals were genotyped on $6 \%$ denaturing polyacrylamide gels stained with silver nitrate (Creste et al., 2001) and sized by comparison to a 10-bp DNA ladder standard (Invitrogen, USA). The number of alleles per locus, observed and expected heterozygosities under Hardy-Weinberg (Nei, 1978), and inbreeding coefficient (f) were estimated (Weir and 
Cockerham, 1984). Analyses were performed with FSTAT 2.9.3.2 (Goudet, 2002), and randomization based tests with Bonferroni's correction were performed to test for deviation from Hardy-Weinberg expectations and for linkage disequilibrium (Goudet et al., 1996). We also estimated the probability of genetic identity (I) (Paetkau et al., 1995) and paternity exclusion probability (Q) (Weir, 1996) for each polymorphic locus and overall loci, using the Identity 1.0 software (Wagner and Sefc, 1999).

\begin{tabular}{|c|c|c|c|c|c|c|c|c|c|c|c|}
\hline Locus & Motif & Primer sequence & TA & Range & NA & $\mathrm{H}_{\mathrm{o}}$ & $\mathrm{H}_{\mathrm{E}}$ & f & I & Q & $\begin{array}{l}\text { Accession } \\
\text { No. }\end{array}$ \\
\hline Hg_E04 & $\mathrm{TA}(7)$ & $\begin{array}{l}\text { F-TGTTGAAGACAGGTGCAAGC } \\
\text { R-TATGCAGCCAACAAGTCTGC }\end{array}$ & 62 & 380 & 1 & 0.000 & 0.000 & NA & - & - & HM545159 \\
\hline Hg_E08 & TGACT (4) & $\begin{array}{l}\text { F-CCTCCCAAGGTTTCTTCCTC } \\
\text { R-GGCCGTCTAACTCTGACTGG }\end{array}$ & 68 & $218-220$ & 2 & 0.000 & 0.282 & 1.000 & 0.581 & 0.122 & HM545160 \\
\hline Hg_E11 & ATA (4) & $\begin{array}{l}\text { F-CCGATGATTGAGACTGTTTTCA } \\
\text { R-GTGCTTTTCCACACACATGC }\end{array}$ & 68 & 425 & 1 & 0.000 & 0.000 & NA & - & - & HM545161 \\
\hline Hg_E12 & TGTA (3) & $\begin{array}{l}\text { F-ACTGCTGAAACGATGAACCC } \\
\text { R-GAGGAAGAAACCTTGGGAGG }\end{array}$ & 68 & $128-140$ & 1 & 0.000 & 0.182 & 1.000 & - & - & HM545162 \\
\hline Hg_E14 & GAAA (3) & $\begin{array}{l}\text { F-GTCTTTGGATTGTGGGAGGA } \\
\text { R-CCTTCCTCCTTTGCCTCTCT }\end{array}$ & 62 & 260 & 1 & 0.000 & 0.000 & NA & - & - & HM545163 \\
\hline Hg_E16 & $\mathrm{AC}(6)$ & $\begin{array}{l}\text { F-AAACTCACGCAGACATGCAG } \\
\text { R-AGTGGACCTTCAACACCCTG }\end{array}$ & 58 & $420-425$ & 2 & 0.200 & 0.456 & 0.561 & 0.425 & 0.188 & HM545164 \\
\hline Hg_E17 & AG (14) & $\begin{array}{l}\text { F-GAGCTCGCTACCGGGGAT } \\
\text { R-TTCATCTGTCGCTCTTGTGC }\end{array}$ & 54 & $146-148$ & 2 & 0.154 & 0.276 & 0.442 & 0.531 & 0.127 & HM545165 \\
\hline Hg_E19 & AAG (14) & $\begin{array}{l}\text { F-GTGCTTGCCAGTGTTTTTGA } \\
\text { R-GGCTTATTCTTAGCTTCTTCTTCTTC }\end{array}$ & 64 & $208-255$ & 11 & 0.715 & 0.901 & 0.207 & 0.034 & 0.738 & HM545166 \\
\hline Hg_E22 & AGGAC (4) & $\begin{array}{l}\text { F-GGATCCGATTGCATTCAGTAA } \\
\text { R-AATTGAGCCAGCTGCAGAGT }\end{array}$ & 68 & $174-176$ & 2 & 0.000 & 0.282 & 1.000 & 0.581 & 0.122 & HM545167 \\
\hline Hg_E24 & $\mathrm{TC}(6)$ & $\begin{array}{l}\text { F-GGGTAGTGGGATACAGAGCG } \\
\text { R-TCAAGCCTCTTGGCAAGTTT }\end{array}$ & 64 & 240 & 1 & 0.000 & 0.000 & NA & - & - & HM545168 \\
\hline General & & & & & & & & 0.551 & 0.0026 & 0.857 & \\
\hline
\end{tabular}

Locus name is followed by repeat motifs present in sequenced fragment, primer sequence, primer annealing temperature in ${ }^{\circ} \mathrm{C}(\mathrm{TA})$, size range of alleles in bp (Range), number of alleles (NA), observed $\left(\mathrm{H}_{\mathrm{O}}\right)$ and expected $\left(\mathrm{H}_{\mathrm{E}}\right)$ heterozygosities, fixation index (f), genetic identity (I), paternity exclusion probability (Q), and GenBank accession number (Accession No.).

A total of $24(5.2 \%)$ of 465 sequenced clones showed nucleotide repeat motifs recognized as microsatellites. Flanking primers were designed for all fragments containing microsatellites, and 10 loci were successfully amplified using a single PCR protocol. Of these 10 microsatellite loci, five displayed no polymorphism and only one polymorphic locus had more than 2 alleles (Hg_E19). Expected heterozygosities ranged from 0.182 to 0.901 , and all polymorphic loci deviated significantly from Hardy-Weinberg equilibrium (Table 1). Combined probability of identity was high (0.0026) and probability of paternity exclusion was low (0.857), showing that further studies on parentage analysis and fine-scale genetic structure will require the search for a new set of polymorphic loci.

Although the number of sequences surveyed in this study was limited, our analysis showed that the relative abundance of microsatellites in the $H$. gymnorhynchus genome was useful as a general source of microsatellite markers. Besides the small number of populations sampled, most loci are tri- and tetranucleotides and show lower levels of polymorphism due to lower mutation rates when compared to dinucleotides (Chakraborty et al., 1997; Ellegren, 2000, 2004). Also, reports on microsatellite characterization suffer from an ascertainment bias because there is selection for the most polymorphic loci during marker development (Ellegren, 
2004). The number of alleles per locus is positively correlated with the number of repeat motifs (Weber, 1990; Taramino and Tingey, 1996; Ellegren, 2004; Brandström and Ellegren, 2008). Although the number of sequences surveyed in this study was limited, our results show that the H. gymnorhynchus genome has a low abundance of microsatellites (only $3.6 \%$ of the sequences showed microsatellites) and also that the repeat length is short, which may limit polymorphism.

The low polymorphism found for three species of Hypostomus from the Paraná Basin for isozymes (Paiva et al., 2005) and in the present study suggests that it could be a characteristic of the Hypostomus group that deserves an in-depth investigation, including more species and populations.

\section{ACKNOWLEDGMENTS}

Research supported by Systema Naturae Consultoria Ambiental, which we gratefully acknowledge. The overall research program in Molecular Ecology of M.P.C. Telles and R.G. Collevatti has been continuously supported by CNPq grants and fellowships.

\section{REFERENCES}

Batista JS, Farias IP, Formiga-Aquino K, Sousa ACB, et al. (2009). DNA microsatellite markers for "dourada" (Brachyplatystoma rousseauxii, Siluriformes: Pimelodidae), a migratory catfish of utmost importance for fisheries in the Amazon: development, characterization and inter-specific amplification. Conserv. Genet. Res. DOI: 10.1007/ s12686-009-9117-5 (online).

Brandström M and Ellegren H (2008). Genome-wide analysis of microsatellite polymorphism in chicken circumventing the ascertainment bias. Genome Res. 18: 881-887.

Carvalho-Costa LF, Hatanaka T and Galetti PM Jr (2006). Isolation and characterization of polymorphic microsatellite markers in the migratory fish Prochilodus costatus. Mol. Ecol. Notes 6: 818-819.

Chakraborty R, Kimmel M, Stivers DN, Davison LJ, et al. (1997). Relative mutation rates at di-, tri-, and tetranucleotide microsatellite loci. Proc. Natl. Acad. Sci U. S. A. 94: 1041-1046.

Covain R and Fisch-Muller S (2007). The genera of the Neotropical armored catfish subfamily Loricariinae (Siluriformes: Loricariidae): a practical key and synopsis. Zootaxa 1462: 1-40.

Creste S, Tulmann Neto A and Figueira A (2001). Detection of single sequence repeat polymorphisms in denaturing polyacrylamide sequencing gels by silver staining. Plant Mol. Biol. Rep. 19: 299-306.

Ellegren H (2000). Heterogeneous mutation processes in human microsatellite DNA sequences. Nat. Genet. 24: 400-402.

Ellegren H (2004). Microsatellites: simple sequences with complex evolution. Nat. Rev. Genet. 5: 435-445.

Goudet J (2002). FSTAT: a program to estimate and test gene diversities and fixation indices.Version 2.9.3.2. Available at [http://www.unil.ch/izea/softwares/fstat.html]. Accessed June 10, 2010.

Goudet J, Raymond M, de Meeus T and Rousset F (1996). Testing differentiation in diploid populations. Genetics 144: 1933-1940.

Martins W, de Sousa D, Proite K, Guimaraes P, et al. (2006). New softwares for automated microsatellite marker development. Nucleic Acids Res. 34: e31.

Morelli KA, Revaldaves E, Oliveira C and Foresti F (2007). Isolation and characterization of eight microsatellite loci in Leporinus macrocephalus (Characiformes: Anostomidae) and cross-species amplification. Mol. Ecol. Notes 7: 32-34.

Morgante M and Olivieri AM (1993). PCR-amplified microsatellites as markers in plant genetics. Plant J. 3: 175-182.

Nei M (1978). Estimation of average heterozygosity and genetic distance from a small number of individuals. Genetics 89: 583-590.

Paetkau D, Calvert W, Stirling I and Strobeck C (1995). Microsatellite analysis of population structure in Canadian polar bears. Mol. Ecol. 4: 347-354.

Paiva S, Renesto E and Zawadzki CH (2005). Genetic structure of Hypostomus (Teleostei, Loricariidae) from the Ribeirão Maringá, a stream of the upper Rio Paraná basin, Brazil. Genet. Mol. Biol. 28: 370-375.

Revaldaves E, Pereira LHG, Foresti F and Oliveira C (2005). Isolation and characterization of microsatellite loci in Pseudoplatystoma corruscans (Siluriformes: Pimelodidae) and cross-species amplification. Mol. Ecol. Notes 5: 463-465. 
Sambrook J and Russell DW (2001). Molecular Cloning: a Laboratory Manual. 3rd edn. Cold Spring Harbor Laboratory Press, Cold Spring Harbor, New York.

Taramino G and Tingey S (1996). Simple sequence repeats for germplasm analysis and mapping in maize. Genome 39: 277-287.

Wagner HW and Sefc KM (1999). IDENTITY, 1.0. Centre for Applied Genetics. University of Agricultural Sciences, Vienna.

Weber RP (1990). Basic Content Analysis. 2nd edn. Sage Publications, Newbury Park.

Weir BS (1996). Genetic Data Analysis. II - Methods for Discrete Population Genetic Data. Sinauer Associates, Sunderland. Weir BS and Cockerham CC (1984). Estimating F-statistics for the analysis of population structure. Evolution 38: 13581370. 